\title{
The Role of Regional / City Governments in Developing and Supervising Of Village Regulation
}

\author{
Adhe Ismail Ananda ${ }^{*)}$ and Sri Kusriyah ${ }^{* *}$ \\ *) Students of Master of Law, Faculty of Law, Universitas Islam Sultan Agung \\ Semarang, email: adheismailananda@gmail.com \\ ${ }^{* *}$ Faculty of Law, Universitas Islam Sultan Agung Semarang
}

\begin{abstract}
The research objective was to identify and analyze the role of district / city government in the guidance and supervision of village regulations. This research method is a normative-empirical approach, by examining Laws and regulations related to the role of district / city local governments in fostering and supervising village regulations with their implementation. The conclusions from the results of this study indicate that in the formation of a Village Regulation, the role of district / city Regional Government is regulated in Article 115 of Act No. 6 of 2014 concerning Villages, one of which is to provide guidelines for drafting village regulations and village head regulations. The technical guidelines for the preparation of village regulations in Kolaka district are regulated in Perda No. 4 of 2009 in its implementation the technical guidelines are still very difficult to adjust to the current conditions due to the issuance of the Law of Permendagri No. 6 of 2014 concerning the Village.
\end{abstract}

Keywords: Coaching; Supervision; Regional Government; Village Regulations; Regent Regulation.

\section{Introduction}

The 1945 Constitution of the Unitary State of the Republic of Indonesia has guaranteed recognition of customary law communities or villages as described in the provisions of Article 18 B paragraph (2), that the State recognizes and respects customary law community units and their traditional rights as long as they are still live and in accordance with the development of society and the principles of the Unitary State of the Republic of Indonesia, which are regulated in law. This then becomes the juridical foundation in the constitution regarding the Village.

The village is a vital part that cannot be separated in the hierarchy of the state structure, because in essence there can be no country without having the smallest parts which in the context of the Indonesian state are usually called villages. ${ }^{1}$ Village or other various designations are referred to as self-governing community because in Indonesia initially it was a local community that had territorial boundaries, was inhabited by a number of residents, and had customs to manage their own area. ${ }^{2}$

Based on the preamble of Act No. 6 of 2014 concerning the Village, ${ }^{3}$ that the Village has original and traditional rights in regulating and managing the interests of the local

\footnotetext{
${ }^{1}$ Moh. Fadli, Jazim Hamid, 2013, Pembentukan Peraturan Desa Partisipatif (Head To Good Village Governance), Malang: UB Press, p. 3.

${ }^{2}$ Ni'matul Huda, 2015, Hukum Pemerintahan Desa "Dalam Konstitusi Indonesia Sejak Kemerdekaan Hingga Era Reformasi, Malang: Setara Press, p. 33.

${ }^{3}$ The preamble to Act No. 6 of 2014 concerning Villages
} 
community and playing a role in realizing the ideals of independence based on the 1945 Constitution of the Republic of Indonesia.

Strengthening the existence of villages is also contained in Act No. 23 of 2014 concerning Regional Government, where one of the duties and functions of the Regency / City Government is to carry out guidance and supervision as stated in Article 380 which states that the Regent / mayor as the head of the regency / city is obliged to carry out guidance and supervision of the Regency / Regional Apparatus. city. ${ }^{4}$

Over time, namely the presence of Act No.. 6 of 2014 concerning Villages, the position of Village Regulations (Perdes) as a product of village law gets a stronger and clearer position. From the provisions of article 69 and article 70 of the Law on Villages, it is regulated, among other things: types of Perdes, the process of forming a Perdes. ${ }^{5}$ In fact, in the provisions of Article 110, the term "Traditional Village Regulation", 6 where the rules are The Traditional Village is adjusted to the customary law and customs norms that apply in the Traditional Village as long as it does not conflict with the provisions of the legislation. In the formation of a Village Regulation, the role of Regional Government is regulated in Article 115 of Act No. 6 of 2014 concerning Villages. Where one of its roles is to provide guidelines for the preparation of village regulations and village head regulations. ${ }^{7}$ Therefore, the problem in this research is what form of guidance and supervision of village regulations carried out by district / city governments.

\section{Research methods}

The method used in this research is juridical-empirical. There are two indicators that will be analyzed in this research, namely the laws and regulations related to the adopted research and its implementation. ${ }^{8}$ Primary data collection with a normative approach is to examine the norms contained in the law, while the empirical approach is to examine the implementation of the law through the interview method at the Kolaka district government with the data source from the Legal Section of the Kolaka District Secretariat. The data obtained is then analyzed by combining normal and empirical approaches to determine the Role of the Kolaka Regency Government in Fostering and Supervising Village Regulations.

\section{Results And Discussion}

\subsection{The Role of the Kolaka Regency Government in Fostering Village Regulations}

The elimination of village regulations in the hierarchy of statutory regulations based on Act No.12 of 2011 does not have implications for the implementation of village

\footnotetext{
${ }^{4}$ Act No. 23 of 2014 concerning Regional Government

${ }^{5}$ Law No. 6 of 2014 concerning the Village

${ }^{6}$ Ibid.

${ }^{7}$ Ibid.

${ }^{8}$ Soerjono Soekanto and Sri Mamuji, 2001, Penelitian Hukum Normatif Suatu Tinjauan Singkat, Jakarta: Raja Grafindu Persada, p. 13.
} 
governance, because village representative bodies, in this case the BPD and the Village Head, can still form village regulations.

Guidance in the administration of Regional government as meant in Act No. 12 of 2017 concerning Guidance and Supervision of the Implementation of Regional Government are efforts, actions and activities aimed at realizing the achievement of the objectives of the administration of Regional Government within the framework of the Unitary State of the Republic of Indonesia. ${ }^{9}$

The supervision carried out by the Regional Government of Kolaka Regency, in this case carried out by the Legal Section of the Regional Secretariat of the Kolaka Regency, has a legal basis which becomes the basis for carrying out its duties, namely in article 115 of Act No. 6 of 2014 concerning Villages that the Regency / City Government Provides Guidelines Drafting Village Regulations and Village Head Regulations and Conducting Evaluation and Supervision of Village Regulations.

The forms of guidance carried out by the Kolaka Regency Government are: ${ }^{10}$

- Forming an Evaluation Team of the Draft Village Regulation which is established through a Regent Decree. In its implementation, the team that was formed through a Regent Decree is carried out annually and this team is chaired directly by the Kolaka Regent as the person in charge. This evaluation team has the task of providing corrections to the content and content that will be included in the draft village regulations, including the suitability of village regulations with village conditions, and whether or not a village regulation is enforced.

- Making Guidelines for Preparing Village Regulations. The Kolaka Regency Government through the Legal Division of the Kolaka Regency Regional Secretariat provides Guidelines for the Formulation of Village Regulations in the form of Regional Regulations, namely Kolaka Regency Regional Regulation Number 4 of 2009 concerning the Formation and Mechanism of Formulating Village Regulations.

According to this article, this form of coaching is still ineffective. Because the basis used by the District Government, in this case the Legal Section of the Kolaka Regency Regional Secretariat, in providing guidance to the formation of village regulations is only based on the general regulations. Whereas the Kolaka Regency Government through the Legal Section of the Kolaka Regency Regional Secretariat can make regulations or technical rules that regulate the form of guidance carried out by the Kolaka Regency Government on existing Village Regulations in Kolaka Regency so that the guidance carried out can be more effective and efficient.

Then the guidelines that are used as the basis for the Village Government in forming Village Regulations are deemed not in sync with the provisions of the existing laws and regulations. Local regulation of Kolaka Regency Number 4 of 2009 concerning the Formation and Mechanism of Formulating Village Regulations must conform to Act No. 6 of 2014 concerning Villages. So that the resulting Village Regulation can be more optimal and in accordance with existing legal principles.

\footnotetext{
${ }^{9}$ Article 1 paragraph (1) of Act No. 12 Of 2017 concerning Guidance and Supervision of Regional Government Administration

${ }^{10}$ Interview with the Head of the Legal Division of the Kolaka Regency Regional Secretariat on October 3, 2018
} 


\subsection{The Role of the Kolaka Regency Government in Supervision of Village Regulations}

According to Bagir Manan, supervision as a control is the same as control. Usually referred to as control which includes the dimensions of supervision related to restrictions and controls related to directives. ${ }^{11}$ The concept of supervision itself, in terms of its implementation stages, is known in two types, namely preventive and repressive supervision. Preventive means actions taken before a decision is issued and repressive is an action taken after a decision is issued. Diana Halim Kuncoro then explained that supervision in the perspective of state administrative law is intended to prevent all forms of deviation from government duties from what has been outlined (preventive) and to act or correct any deviations that occur (repressive). ${ }^{12}$

According to Paulus Efendi Lotulung, the main objective of controlling the government (controle) is to prevent mistakes, whether intentional or unintentional, as a preventive effort, or also to correct them if there has been an error, as a repressive effort. In a country based on people's sovereignty and based on the law, a preventive supervision system should be avoided as much as possible, because this supervision seems to punish an act that has not been carried out, the main supervision is repressive supervision. $^{13}$

Supervision of legal products can be interpreted as an act to evaluate a regulation. Supervision is carried out by a state institution that is authorized by statutory regulations in the form of prevention or cancellation if there is a conflict with other regulations or higher regulations. ${ }^{14}$

In the context of regulation, preventive supervision is an effort made before a draft regulation is ratified to become a statutory regulation and repressive supervision is an effort made after the enactment of a draft regulation into statutory regulation. ${ }^{15}$ Preventive supervision is associated with goedkeuring and repressive oversight of vernietiging or schorsing powers.

According to Jimly Asshidiqie the concept of supervision is then divided into 3 (three) groups, namely:

- Control of legal norms through political supervision or control (legislative control / legislative review)

- Supervision or administrative control (administrative control / executive review)

\footnotetext{
${ }^{11}$ Bagir Manan, Peningkatan Fungsi Kontrol Masyarakat Terhadap Lembaga Legislatif, Eksekutif dan Yudikatif, Paper at the National Kosgoro Orientation and Face-to-Face Forum, Cipanas-Cianjur, 26 July 2000, p. 1-2.

${ }^{12}$ SF. Marbun, et al, 2004, Dimensi-Dimensi Hukum Administrasi Negara, Yogyakarta: UII Press, p. 267.

${ }^{13}$ Solechan. Memahami Peran Ombudsman Sebagai Badan Pengawas Penyelenggaraan Pelayanan Publik di Indonesia, Administrative Law \& Governance Journal, Vol. 1 No 1 (2018), url:https://ejournal2.undip.ac.id/index.php/alj/article/view/2757

${ }^{14}$ Sulistyo, Y., Antikowati, A., \& Indrayati, R, Pengawasan Pemerintah Terhadap Produk Hukum Daerah (Peraturan Daerah) Melalui Mekanisme Pembatalan Peraturan Daerah Berdasarkan Undang-Undang Nomor 32 Tahun 2004 Tentang Pemerintahan Daerah, Lentera Hukum Jurnal Vol. 1 No 1 (2014) url:http://jurnal.unej.ac.id/index.php/eJLH/article/view/559

${ }^{15}$ Sukma NM, Analisis Yuridis Pembatalan Perda Oleh Menteri Dalam Negeri, Galuh Justisi Scientific Journal, Vol. 5 No 1 (2017) url:

https://jurnal.unigal.ac.id/index.php/galuhjustisi/article/view/150
} 
- Legal supervision or legal control (judicial control / judicial review). ${ }^{16}$

Political oversight (legislative review) is supervision carried out by a political body. Mauro Cappelleti explained that political testing is more of a preventive nature, namely testing is carried out before a law is promulgated (promulgation). This preventive action has positive aspects, because the possibility of unwanted risks or impacts can be avoided, because the law has not been implemented (not yet enacted), which means that it does not have binding legal consequences. ${ }^{17}$

In practice, the authority for legislative review is given to the legislative body itself. ${ }^{18}$ The action that is then taken is evaluating the existing legal products to be revised or replaced by new laws. Materially, the evaluation is carried out on the basis that there is a conflict with the higher-level laws, in this case the constitution, while at the regional level, if there is a conflict with the higher level laws and regulations. In addition, this evaluation can also be carried out when existing legal products are no longer in accordance with the development of community life and are not in accordance with the interests of the community which are none other than the welfare of the people as holders of sovereignty.

Efforts to control legal norms carried out by administrative institutions are carried out in order to carry out management functions in the executive sector. The government as the implementer of the law can evaluate a legal product that it will implement by initiating changes to the law concerned if it cannot be implemented, because it conflicts with other laws or conflicts with the state constitution. This control mechanism carried out by the executive agency is then called an administrative review. ${ }^{19}$

Supervision carried out by administrative officials is actually relevant to the application of a government system with the concept of regional autonomy. In general, the target of government supervision is the maintenance and maintenance so that the welfare state law can run well and can also bring government power as the organizer of the welfare of the community to good implementation and within the limits of its power. ${ }^{20}$ In the context of autonomy, the central government with its powers will supervise the lower government running according to the authority given to it. Likewise, legal products produced such as regional regulations contain material in accordance with the scope of authority that the region has. ${ }^{21}$

Administrative review In fact, it tends to be a preventive action against regulatory products, namely regulations, meanwhile, it becomes repressive against legal products that are administrative in nature such as decisions known as administrative appeals. Preventive actions in the supervision of legal products are structural and specific in nature, which can be realized in the following forms: first, asking for consideration

\footnotetext{
${ }^{16}$ Jimly Asshiddiqie, 2006, Hukum Acara Pengujian Undang-Undang, Second Edition, Jakarta: Secretariat, General and Registrar of the Constitutional Court of the Republic of Indonesia, p. 1

${ }^{17}$ Ni'matul Huda, 2005, Negara Hukum, Demokrasi dan Judicial Review, Yogyakarta: UII Press, p. 91.

${ }^{18}$ Nurul Qamar, Kewenangan Judicial Review Mahkamah Konstitusi , Constitutional Journal Vol. 1 No 1 (2012) url:

https://jk.ejournal.unri.ac.id/index.php/JK/article/view/2081

${ }^{19}$ Jimly Asshiddiqie, 2006, Perihal Undang-Undang, Jakarta: Constitution Press, p. 6.

${ }^{20}$ lbid, p. 7.

${ }^{21}$ Setiawan Irfan, 2018, Handbook Pemerintahan Daerah, Yogyakarta: Forum for Resolution, p. 22.
} 
before the regulation is stipulated into a regulation; second, submission of the stipulated legal product to the superior government of a higher level to obtain endorsement so that it can be enforced by granting a period of ratification. ${ }^{22}$.

Supervision of a legal product that is carried out by a judicial power institution or court is called judicial control. In terms of terms there is a difference between toetsingrecht and a judicial review. Both are influenced by the legal system applied by a country, where toetsingrecht (right to test) is applied through a centralized judicial institution by a state with a civil law legal system, while judicial review is applied through every tiered judicial institution by a country with a common law system. ${ }^{23}$

Supervision of all local government actions by The Central Government includes decrees of Regional Heads and Regional Regulations since Regional Autonomy was first enforced until now, Act No. 23 of 2014 recognizes three types of supervision, namely General Supervision, Repressive Supervision, and Preventive Supervision.

The form of supervision carried out by the Kolaka Regency Government is to emphasize repressive supervision, namely by forming a Team of Clarification of Village Regulations that have been promulgated. In its implementation, the team that was formed through a district head decree is also carried out annually. The Clarification Team will examine the Village Regulation that has been enacted and then produce clarification results. The results of the Team's Clarification are the results of clarification of Village Regulations that are in accordance with the public interest or the provisions of higher laws and regulations. ${ }^{24}$

In the event that the results of the clarification of the Village Regulation do not conflict with the public interest and the provisions of the higher laws and regulations, a clarification letter will be issued containing the appropriate clarification results. However, if the clarification results contradict the public interest and the provisions of the higher laws and regulations, the Village Regulation is canceled through a Regent Decree. $^{25}$

In its implementation, until now there has been no village whose village regulations are against the public interest or higher legislation. Because the Kolaka District Government always coordinates with the Kolaka Regency Government through the Legal Section of the Kolaka Regency Regional Secretariat before making a Village Regulation. However, there are several villages that do not carry out a coordination system before making village regulations. Villages that do not carry out this coordination will be recorded and then direct guidance and supervision will be carried out to the officials who are obliged to establish Village Regulations, namely the Village Head and BPD.

The main problem that was found was the lack of Human Resources from the Local Government and Village Government. So that it has an impact on the facts that have emerged in the Villages, namely, there is still the practice of Copy Paste in Making

\footnotetext{
${ }^{22}$ Imam Soebechi, 2012, Judicial Review Perda Pajak dan Retribusi Daerah, Jakarta: Sinar Grafika, p. 17.

${ }^{23}$ Nina Jayanti, Mekanisme Pengawasan Terhadap Produk Hukum Dalam Konstruksi Politik Hukum, $\begin{array}{lllllll}\text { Tambun B River Journal of Law Science Vol.4 No } 2 & \text { (2019) }\end{array}$ url:http://journal.stihtb.ac.id/index.php/iihtb/article/view/84

${ }^{24}$ Interview with the Head of the Legal Division of the Kolaka Regency Regional Secretariat on October 3 , 2018

${ }^{25}$ Ibid.
} 
Village Regulations, the low level of Village initiative in making Village Regulations, as well as minimal training for Villages.

According to the author, the concept of supervision given to legal products in the village tends to be Administrative review Supervision. And this is an effective supervision concept because of its tendency to take preventive action against regulatory products, namely village regulations. This can be seen in the Preventive Actions in the supervision of structural and specific legal products, namely the existence of several villages in Kolaka Regency that asked for consideration before the regulation was enacted into a regulation then the submission of the stipulated legal product to the superior government of a higher level to obtain approval so that can be enforced by granting the validation period.

\section{Closing}

\subsection{Conclusion}

The form of guidance carried out by the Kolaka Regency Government in the Formation of Village Regulations is by forming an Evaluation Team of the Village Regulation Plan stipulated by a Regent Decree and Making Technical Guidelines for the Preparation of Village Regulations through Kolaka Regency Regional Regulation Number 4 of 2009 concerning the Formation and Mechanism of Formulating Village Regulations. However, the Regional Regulation in question is still in the process of revision because it has to conform to Act No. 6 of 2014 concerning Villages, but the technicality of its preparation is not much different from the existing regulations. After the Guidelines for Preparing Village Regulations have been completed, they will be distributed to each village in the Kolaka Regency area as a reference in making and compiling Village Regulations.

While the form of supervision carried out by the Regional Government of Kolaka Regency is to focus on repressive supervision, namely by forming a Team of Clarification of Village Regulations that have been promulgated. In its implementation, the team that was formed through a district head decree is also carried out annually. The Clarification Team will examine the Village Regulation that has been enacted and then produce clarification results. The results of the Team's Clarification are the results of clarification of Village Regulations that are already in accordance with the public interest or the provisions of higher laws and regulations. In the event that the results of the clarification of the Village Regulation do not conflict with the public interest and the provisions of the higher laws and regulations, a clarification letter will be issued containing the appropriate clarification results.

\subsection{Suggestion}

The Kolaka Regency Government through the Legal Division of the Kolaka Regency Regional Secretariat must be more optimal in carrying out its duties related to guidance and supervision of the Formation of Village Regulations. One of them is by increasing Human Resources for Village Officials who have competence in the Formation of Village Regulations, namely the Village Head and BPD by compiling 
technical regulations related to how to form Guidance and Supervision of the Formation of Village Regulations in this case the regent regulation.

\section{Bibliography}

\section{Journal:}

Nina Jayanti, Mekanisme Pengawasan Terhadap Produk Hukum Dalam Konstruksi Politik Hukum, Tambun B River Journal of Law Science Vol.4 No 2 (2019) url: http://journal.stihtb.ac.id/index.php/jihtb/article/view/84

Nurul Qamar, Kewenangan Judicial Review Mahkamah Konstitusi, Constitutional Journal Vol. 1 No 1 (2012) url:

https://jk.ejournal.unri.ac.id/index.php/JK/article/view/2081

Solechan, Memahami Peran Ombudsman Sebagai Badan Pengawas Penyelenggaraan Pelayanan Publik di Indonesia, Administrative Law \& Governance Journal, Vol. 1 No 1 (2018), url: https://ejournal2.undip.ac.id/index.php/alj/article/view/2757

Sukma NM, Analisis Yuridis Pembatalan Perda Oleh Menteri Dalam Negeri, Galuh $\begin{array}{lllllll}\text { Justisi Scientific Journal, Vol. } & 5 & \text { No } & 1 & \text { (2017) }\end{array}$ url:https://jurnal.unigal.ac.id/index.php/galuhjustisi/article/view/150

Sulistyo, Y., Antikowati, A., \& Indrayati, R, Pengawasan Pemerintah Terhadap Produk Hukum Daerah (Peraturan Daerah) Melalui Mekanisme Pembatalan Peraturan Daerah Berdasarkan Undang-Undang Nomor 32 Tahun 2004 Tentang Pemerintahan Daerah, Lentera Hukum Jurnal Vol. 1 No 1 (2014) url: http://jurnal.unej.ac.id/index.php/eJLH/article/view/559

\section{Book:}

Bagir Manan, Peningkatan Fungsi Kontrol Masyarakat Terhadap Lembaga Legislatif, Eksekutif dan Yudikatif, Paper at the Kosgoro National Level Orientation and Face-to-Face Forum, Cipanas-Cianjur, 26 July 2000.

Imam Soebechi, Judicial Review Perda Pajak dan Retribusi Daerah, Jakarta: Sinar Grafika, 2012.

Jimly Asshiddiqie, 2006, Hukum Acara Pengujian Undang-Undang, Second Edition, Jakarta: Secretariat, General and Registrar of the Constitutional Court of the Republic of Indonesia

Jimly Asshiddiqie, 2006, Perihal Undang-Undang, Jakarta: Constitution Press

Moh. Fadli, Jazim Hamid, 2013, Pembentukan Peraturan Desa Partisipatif (Head To Good Village overnance), Malang: UB Press

Ni'matul Huda, 2015, Hukum Pemerintahan Desa "Dalam Konstitusi Indonesia Sejak Kemerdekaan Hingga Era Reformasi", Malang: Setara Press

Ni'matul Huda, 2005, Negara Hukum, Demokrasi dan Judicial Review, Yogyakarta: UII Press

Setiawan Irfan, 2018, Handbook Pemerintahan Daerah, Yogyakarta: Forum for Resolution.

SF. Marbun, et al, 2004, Dimensi-Dimensi Hukum Administrasi Negara, Yogyakarta: UII Press. 
- Jurnal Daulat Hukum

Volume 3 Issue 3, September 2020

ISSN: 2614-560X Singkat, Jakarta: Raja Grafindo Persada
The Role of Regional / City Governments in...

(Adhe Ismail Ananda)

\section{Soerjono Soekanto and Sri Mamuji, 2001, Penelitian Hukum Normatif Suatu Tinjauan}

\author{
Singkat, Jakarta: Raja Grafindo Persada
}

